\title{
Patterns of rapid weight loss in elite sambo athletes
}

\author{
Patrik Drid ${ }^{1 *}$, Flavia Figlioli², Nemanja Lakicevic ${ }^{2}$, Ambra Gentile², Valdemar Stajer ${ }^{1}$, Bojan Raskovic ${ }^{1}$, Nina Vojvodic ${ }^{1}$, \\ Roberto Roklicer ${ }^{1}$, Tatjana Trivic ${ }^{1}$, Sergey Tabakov ${ }^{3}$, Sergey Eliseev ${ }^{3}$ and Antonino Bianco ${ }^{2}$
}

\begin{abstract}
Background: Rapid weight loss (RWL) is commonly practiced in combat sports. Both magnitude and methods used to induce RWL are largely similar among combat sports, but currently, there is no data on RWL methodology used by sambo athletes. Therefore, the aim of this study was to determine RWL procedures sambo athletes apply to lose weight rapidly.

Methods: The sample consisted of 199 participants, of which 132 males and 67 females who participated in the World Sambo Championship 2020 held in Novi Sad, Serbia. Each participant received RWL questionnaire that was available in multiple languages, and every participant was instructed how to fill it out.

Results: Almost $87 \%$ of sambo participants declared to have intentionally cut their weight prior to the competition, whereby $5.27 \mathrm{~kg}$ (SD: \pm 7.57$)$ was lost. Gradual dieting, sauna use and skipping meals were the most dominant methods used to reduce weight prior to competition while more extreme methods of RWL such as the use of laxatives, diuretics, diet pills and vomiting were also implemented but by much smaller fragment of the participants involved.

Conclusions: Findings from our study largely match with previously conducted RWL studies in terms of prevalence, magnitude and methods used by combat sport athletes, especially in judo and wrestling. Knowing the hazardous consequences of RWL, alternative methods of sustainable weight loss should be considered.
\end{abstract}

Keywords: Weight control, Weight classes, Combat sports, Martial arts

\section{Background}

Prior to 1940s the Committee of Sports of Union of Soviet Socialist Republics declared sambo to be the official combat sport of the Soviet Union [1]. In the decades to follow, sambo gained considerable attention in the post World War II Soviet Union states, but also on a global scale. After 80 years of its acknowledgment and development, sambo has recently received temporary recognition from the International Olympic Committee which is a first step towards inclusion in the Olympic Games [2].

\footnotetext{
* Correspondence: patrikdrid@gmail.com

${ }^{1}$ Faculty of Sport and Physical Education, University of Novi Sad, Lovcenska 16, Novi Sad 21000, Serbia

Full list of author information is available at the end of the article
}

Elite athletes are always aiming for a peak performance throughout the year. Sambo athletes are no different. Besides maintaining excellent physical shape and technical skills [3, 4], sambo athletes must maintain their optimal competitive weight for championships, given sambo is a weight-divided sport [2]. Thus, meticulous preparations (efficient training, adequate diet, sufficient sleep and recovery) are critical for every training session but especially for competitions. With regards to competitions and diet, studies reveal that nearly $90 \%$ of both male and female judo athletes engage in rapid weight loss (RWL) before the competition [5] to possibly gain competitive advantage over their lighter opponents. Similar trends have been observed in wrestling [6-8]. This approach of

(c) The Author(s). 2021 Open Access This article is licensed under a Creative Commons Attribution 4.0 International License, which permits use, sharing, adaptation, distribution and reproduction in any medium or format, as long as you give appropriate credit to the original author(s) and the source, provide a link to the Creative Commons licence, and indicate if changes were made. The images or other third party material in this article are included in the article's Creative Commons licence, unless indicated otherwise in a credit line to the material. If material is not included in the article's Creative Commons licence and your intended use is not permitted by statutory regulation or exceeds the permitted use, you will need to obtain permission directly from the copyright holder. To view a copy of this licence, visit http://creativecommons.org/licenses/by/4.0/ The Creative Commons Public Domain Dedication waiver (http://creativecommons.org/publicdomain/zero/1.0/) applies to the data made available in this article, unless otherwise stated in a credit line to the data. 
weight reduction is defined as a $5 \%$ weight loss achieved over 5-7 days $[9,10]$. Regardless of the type of combat sport, methods of inducing RWL are very similar and are often initiated by reduced ingestion of fluids, caloric deficiency, increased training levels, plastic suit training, heated room training, and sauna use [7, 11-13]. Nevertheless, RWL procedure can cause many health complications that can affect the body acutely or chronically [14]. It is even more disturbing that some athletes declared performing RWL up to 10 times a year [5].

However, so far, no data has been obtained on RWL methods in sambo athletes. Therefore, the aim of this study was to identify the methodology and magnitude of RWL used by sambo athletes with a particular emphasis on sex-based differences.

\section{Methods}

\section{Study design}

To determine methods of RWL used by sambo athletes, we adopted RWL questionnaire developed by Artioli et al. [15]. The questionnaire consists of 21 items relating to personal information, competitive level, weight and diet history, and RWL behaviors, including the source of influence (e.g., teammates, coach, trainers, physician) and the methods used to cut weight before competition (e.g., vomiting, using pills, dieting, fasting, and so on) [15]. To ensure honest answers, we guaranteed that the questionnaire was totally anonymous. The original version of the questionnaire in Portuguese was used, and was further translated into Russian, French, Serbian, and Spanish language to facilitate data collection. Athletes were asked to fill out questionnaire in the sports hall where the competition took place. In case any questions were unclear, researchers were available to provide detailed explanation. Also, if any miscommunication was noted, a translator speaking all of the abovementioned languages was there to clarify details of the questionnaire.

\section{Participants}

The sample consisted of 199 participants, of which 132 males (66.3\%) and 67 females (33.7\%). The mean age of the sample was 21.70 years (SD: \pm 5.22 ) for females and 23.16 years (SD: \pm 6.08 ) for males. The average height was $1.64 \mathrm{~m}$ (SD: \pm 0.09 ) for females and $1.75 \mathrm{~m}$ (SD: \pm 0.10 ) for males, while the average weight was $64.58 \mathrm{~kg}$ (SD: \pm 14.90 ) for females and 75.22 (SD: \pm 17.78 ) for males.

Participants from 20 countries took part in the study: Ukraine (20.1\%), France (15.6\%), Serbia (12.1\%), Russia (11.1\%), Moldavia (10.6\%), Spain (7.5\%), Uzbekistan (7.0\%), Cameroon (3.0\%), Bulgaria (2.5\%), Kyrgyzstan (2.0\%), Colombia (1.5\%), Belarus (1.0\%), Belgium (1.0\%), Croatia (1.0\%), Italy (1.0\%), USA (1.0\%), Lithuania
(0.5\%), Mexico (0.5\%), South Africa (0.5\%) and Tajikistan (0.5\%).

The study was conducted according to the Helsinki declaration and ethical approval was obtained from ethics committee of University of Novi Sad, Serbia (Ref. No. 46-06-02/2020-1). All sambo athletes gave written informed consent upon agreement to participate. Since 30 participants were minor (younger than 18), written consent was obtained from their national team coach as their legal guardian during the championship.

\section{Statistical analysis}

Obtained data were analyzed using SPSS statistical software (ver. 23.0). Descriptive statistics were first calculated on all the variables involved, including height, weight, athletic experience, RWL frequency, RWL methodology, and influence in weight-cutting practices. Gender differences regarding the amount of weight loss and regain were evaluated through $\mathrm{t}$-test, while differences in RWL techniques and influences were calculated through the Wilcoxon Rank Sum test. The significance level was set at $\alpha=0.05$.

\section{Results}

The average sambo experience of the participants was 11.37 years (SD: \pm 6.44 ). Most participants declared to have won at least one medal at international level (74.4\%). The $86.9 \%(n=173)$ of sambo participants declared to have intentionally cut their weight prior to the competition. In addition, athletes reported performing their first RWL at age 15.77 (SD: \pm 3.54 ). The sample declared to cut around $5.27 \mathrm{~kg}$ (SD: \pm 7.57 ) of body weight on average and usually started doing so 11.87 (SD: \pm 9.51) days before the competition (Table 1).

There were no significant gender differences in the amount of reduced weight, in both absolute and relative terms (Males: $-8.49 \%$; Females: - 5.59\%; Mean $_{\text {males: }} 5.82$ $\mathrm{kg}$, Mean $_{\text {females: }}: 3.30 \mathrm{~kg}, p=0.15$,). Females started before males to cut weight prior to competition $\left(\mathrm{Mean}_{\mathrm{fe}}\right.$ males: 14.88 days, Mean $_{\text {males: }}$ 16.22 days, $\left.p=0.015\right)$ and tended to regain less weight than their male counterparts (Males: $+11.70 \%$; Females: $+6.42 \%$; Mean $_{\text {females: }}$ : $3.83 \mathrm{~kg}$, Mean males: $8.06 \mathrm{~kg}, p=0.03$ ) (Fig. 1).

The most common methods used to cut the weight rapidly (calculated as the sum of the answers "always" and "sometimes") was gradual dieting (80.5\%), followed by sauna $(75.9 \%)$, skipping meals $(70.7 \%)$, training with plastic suits $(63.8 \%)$, not ingesting fluids $(62.1 \%)$, training in a heated room (60.9\%), increased exercise (58.0\%), fasting (44.8\%) and spitting (44.8\%). Less common methods adopted were the use of laxatives (16.1\%), diuretics $(13.2 \%)$, diet pills (10.9\%) and vomiting (9.8\%) (Table 2). 
Table 1 Weight reduction history reported by the sambo competitors

\begin{tabular}{|c|c|c|c|c|c|}
\hline \multirow[t]{2}{*}{ Questions } & \multicolumn{2}{|l|}{ Males } & \multicolumn{2}{|c|}{ Females } & \multirow[t]{2}{*}{$p^{a}$} \\
\hline & Mean & SD & Mean & SD & \\
\hline How many times did you cut weight to compete last season? (number of times) & 4.41 & 8.35 & 3.51 & 3.03 & 0.43 \\
\hline How many days before competition do you usually cut weight? (start days) & 10.97 & 9.88 & 12.04 & 9.10 & 0.50 \\
\hline \multirow[t]{2}{*}{ At what age did you start to cut weight before the competition? (yrs.) } & 16.22 & 3.57 & 14.88 & 3.33 & $0.015^{*}$ \\
\hline & \multicolumn{2}{|l|}{$\Delta(\%)$} & \multicolumn{2}{|l|}{$\Delta(\%)$} & \\
\hline How much weight do you usually cut before the competition? (kg) & \multicolumn{2}{|l|}{-8.49} & \multicolumn{2}{|l|}{-5.59} & 0.15 \\
\hline What is the most weight you have cut to compete in your career? $(\mathrm{kg})$ & \multicolumn{2}{|l|}{-14.60} & \multicolumn{2}{|l|}{-13.30} & 0.80 \\
\hline How much weight do you usually regain after the competition? (kg) & \multicolumn{2}{|l|}{11.70} & \multicolumn{2}{|l|}{6.42} & $0.03^{*}$ \\
\hline
\end{tabular}

${ }^{a}$ t-test comparison between male and female athletes

With respect to gender differences in the methods used for cutting weight, Wilcoxon Rank Sum test showed non-significant outcomes for all the RWL methods.

Participants declared that they were very influenced or somehow influenced by their coach (60.1\%). Physicians and dietitians were not influential for most athletes (58.4 and 62.6\%, respectively) (Table 3). Wilcoxon Rank Sum test did not evidence any gender difference among the various figures of influence.

\section{Discussion}

The aim of this study was to determine the methods sambo athletes use to induce RWL. Acquired data shows that gradual dieting, sauna use and skipping meals were the most common methods used to reduce weight prior to competition in both males and females. However, more extreme methods of RWL such as the use of laxatives, diuretics, diet pills and vomiting were not frequently used. The latter is especially worrisome not strictly because diuretics are prohibited by the World Anti-Doping Agency [16] and are responsible for a significant number of doping cases in combat sports [17], but because the devastating effects they can leave on one's health [18]. Overall, males tended to lose more weight during RWL while also regaining more weight after RWL when compared to females. Findings from our study are largely similar to findings by Artioli et al. [5] where the most commonly used RWL methods by judoist were gradual dieting, increased exercising, skipping meals and restricted fluid ingestion. In addition, several studies on RWL methodology in high-school and college wrestlers show similar data $[7,19]$. In other combat sports such as mixed martial arts, jujitsu, Brazilian jiu jitsu, boxing, taekwondo and kickboxing, prevalance of RWL ranges from 60 to $80 \%$ [11, 13, 20-22]. Therefore, detected RWL trends are not unique to sambo, judo or wrestling athletes but are omnipresent in varied degrees in combat sports in general.

Our study showed that coaches were the most important figure influencing sambo athletes to pursue RWL. Berkovich et al. [23] found identical results in his study on judo and taekwondo coaches and trainers. The same study showed that coaches and trainers encouraged athletes to engage in RWL as early as 12 years old. In our case, athletes reported starting RWL at $\sim 16$ years of age. This should come as no surprise since literature showed that even 5 year old wrestlers are pressured to engage in

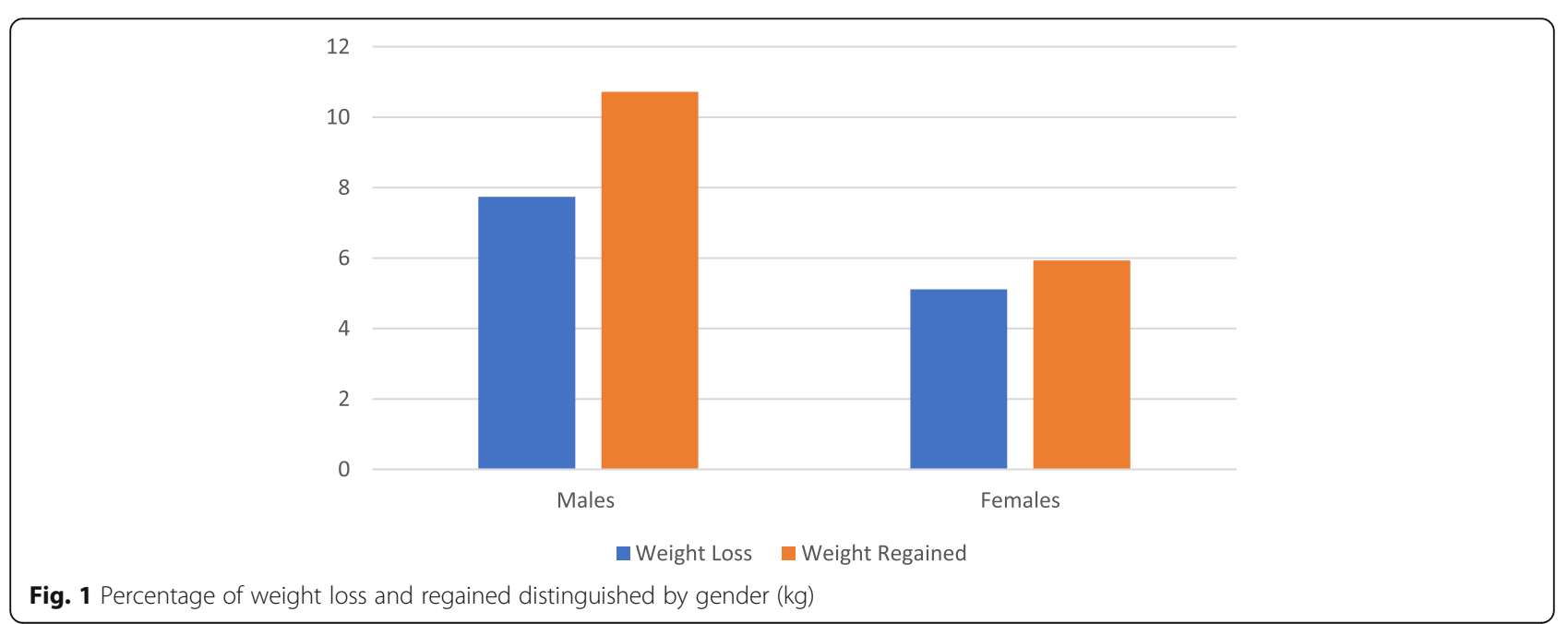


Table 2 Frequency distribution for weight loss methods reported by the sambo competitors

\begin{tabular}{|c|c|c|c|c|c|}
\hline Methods & I do not use it anymore & Never used & Rarely & Sometimes & Always \\
\hline Gradual dieting (\%) & 3.4 & 6.3 & 9.8 & 35.6 & 44.8 \\
\hline Males & 5.1 & 7.7 & 8.5 & 30.8 & 47.9 \\
\hline Females & 0 & 3.5 & 12.3 & 45.6 & 38.6 \\
\hline Skipping 1 or 2 meals (\%) & 2.9 & 10.3 & 16.1 & 53.4 & 17.2 \\
\hline Males & 3.4 & 11.1 & 17.9 & 51.3 & 16.2 \\
\hline Females & 1.8 & 8.8 & 12.3 & 57.9 & 19.3 \\
\hline Fasting (\%) & 8.0 & 30.5 & 16.7 & 37.9 & 6.9 \\
\hline Males & 7.7 & 32.5 & 21.4 & 32.5 & 6.0 \\
\hline Females & 8.8 & 26.3 & 7.0 & 49.1 & 8.8 \\
\hline Restricting fluid ingestion (\%) & 2.3 & 15.5 & 20.1 & 40.8 & 21.3 \\
\hline Males & 1.7 & 17.1 & 21.4 & 41.0 & 18.8 \\
\hline Females & 3.5 & 12.3 & 17.5 & 40.4 & 26.3 \\
\hline Increased exercise (\%) & 8.0 & 1.7 & 32.2 & 23.0 & 35.1 \\
\hline Males & 9.4 & 2.6 & 35.9 & 17.9 & 34.2 \\
\hline Females & 5.3 & 0 & 24.6 & 33.3 & 36.8 \\
\hline Training in heated room (\%) & 0.6 & 16.1 & 22.4 & 37.4 & 23.6 \\
\hline Males & 0.9 & 16.2 & 23.1 & 34.2 & 25.6 \\
\hline Females & 0 & 15.8 & 21.1 & 43.9 & 19.3 \\
\hline Sauna (\%) & 4.0 & 9.8 & 10.3 & 43.7 & 32.2 \\
\hline Males & 3.4 & 8.5 & 12.8 & 41.9 & 33.3 \\
\hline Females & 5.3 & 12.3 & 5.3 & 47.4 & 29.8 \\
\hline Training in plastic suits (\%) & 2.9 & 14.9 & 18.4 & 36.2 & 27.6 \\
\hline Males & 1.7 & 12.0 & 21.4 & 33.3 & 31.6 \\
\hline Females & 5.3 & 21.1 & 12.3 & 42.1 & 19.3 \\
\hline Use plastic suit all day (\%) & 2.9 & 40.2 & 19.5 & 23.6 & 13.8 \\
\hline Males & 0.9 & 39.3 & 23.1 & 21.4 & 15.4 \\
\hline Females & 7.0 & 42.1 & 12.3 & 28.1 & 10.5 \\
\hline Spitting (\%) & 3.4 & 36.2 & 15.5 & 36.2 & 8.6 \\
\hline Males & 3.4 & 31.6 & 14.5 & 41.9 & 8.5 \\
\hline Females & 3.5 & 45.6 & 17.5 & 24.6 & 8.8 \\
\hline Laxative (\%) & 5.2 & 67.8 & 10.9 & 13.2 & 2.9 \\
\hline Males & 1.7 & 68.4 & 12.0 & 14.5 & 3.4 \\
\hline Females & 12.3 & 66.7 & 8.8 & 10.5 & 1.8 \\
\hline Diuretics (\%) & 5.2 & 75.3 & 6.3 & 10.9 & 2.3 \\
\hline Males & 2.6 & 10.3 & 6.8 & 76.1 & 4.3 \\
\hline Females & 1.8 & 12.3 & 5.3 & 73.3 & 7.0 \\
\hline Diet pills (\%) & 2.9 & 79.3 & 6.9 & 6.9 & 4.0 \\
\hline Males & 1.7 & 78.6 & 8.5 & 6.8 & 4.3 \\
\hline Females & 5.3 & 80.7 & 3.5 & 7.0 & 3.5 \\
\hline Vomiting (\%) & 4.6 & 78.2 & 7.5 & 8.6 & 1.1 \\
\hline Males & 3.4 & 77.8 & 8.5 & 8.5 & 1.7 \\
\hline Females & 7.0 & 78.9 & 5.3 & 8.8 & 0.0 \\
\hline
\end{tabular}


Table 3 Frequency distribution for the persons who are influential on the weight management behaviors reported by the sambo competitors

\begin{tabular}{|c|c|c|c|c|c|}
\hline Source of influence & Not influential & Little influential & Unsure & Somehow influential & Very influential \\
\hline Teammate (\%) & 33.1 & $27.3 \%$ & $5.8 \%$ & 19.8 & 14.0 \\
\hline Males & 33.0 & 27.8 & 6.1 & 19.1 & 13.9 \\
\hline Females & 33.3 & 26.3 & 5.3 & 21.1 & 14.0 \\
\hline Fellow wrestler (\%) & 38.2 & 20.2 & 13.3 & 19.1 & 9.2 \\
\hline Males & 35.3 & 21.6 & 12.9 & 19.8 & 10.3 \\
\hline Females & 43.9 & 17.5 & 14.0 & 17.5 & 7.0 \\
\hline Physician (\%) & 58.4 & 19.7 & 6.9 & 10.4 & 4.6 \\
\hline Males & 54.7 & 17.9 & 9.4 & 14.5 & 3.4 \\
\hline Females & 66.1 & 23.2 & 1.8 & 1.8 & 7.1 \\
\hline Personal Trainer (\%) & 43.4 & 16.8 & 6.4 & 20.8 & 12.7 \\
\hline Males & 44.4 & 20.5 & 6.8 & 17.1 & 11.1 \\
\hline Females & 41.1 & 8.9 & 5.4 & 28.6 & 16.1 \\
\hline Coach (\%) & 16.3 & 14.5 & 8.7 & 28.5 & 32.0 \\
\hline Males & 17.2 & 16.4 & 11.2 & 24.1 & 31.0 \\
\hline Females & 14.3 & 10.7 & 3.6 & 37.5 & 33.9 \\
\hline Parents (\%) & 41.6 & 19.1 & 6.4 & 16.2 & 16.8 \\
\hline Males & 45.3 & 17.1 & 6.8 & 15.4 & 15.4 \\
\hline Females & 33.9 & 23.2 & 5.4 & 17.9 & 19.6 \\
\hline Dietitian (\%) & 62.6 & 13.2 & 8.0 & 9.8 & 6.3 \\
\hline Males & 57.3 & 17.1 & 8.5 & 10.3 & 6.8 \\
\hline Females & 73.7 & 5.3 & 7.0 & 8.8 & 5.3 \\
\hline
\end{tabular}

RWL [24]. The American Academy of Pediatrics stresses that this practice needs to be avoided at this age as it interferes with children's and adolescents' normal growth and development and can cause psychological issues [25].

Coming from a perspective that prioritizes athlete's health and safety, it is important to outline that RWL practice is not without consequences. Existing literature eloquently describes RWL-induced physical and psychological consequences, which can range from acute to chronic [14], with repetitive RWL offering no protection for athletes from the negative impact of RWL on performance [26]. In fact, ever since 1996 eminent healthand fitness organizations such as the American College of Sports Medicine, have unambiguously stated that there is a general consensus that RWL has a negative impact on physiological and health-related parameters [27]. Despite these „early "warnings and some RWLrelated regulations implemented in National Collegiate Athletic Association in United States [28], recent studies, including ours, reveal that tendencies regarding RWL in combat sports have not changed significantly [29]. It is important to outline that RWL is not necessarily associated with competitive success [30] or good performance $[31,32]$, and therefore the premise that lighter opponent will be likely the one to lose in the competition setting is questionable. However, oftentimes RWL is popularly perceived as a mental toughness practice that gives athletes a psychological advantage over their opponents [33]. Contrary to this belief, a recent systematic review on the impact of RWL on judo athletes by Lakicevic et al. [14] showed that the feelings of tension, anger, and fatigue significantly increased, while a decrease in vigor was demonstrated among judo athletes who practice RWL. As more and more emerging studies reveal harmful effects of RWL [9, 34-38] which can even lead to lethal consequences [39], scientists suggested that this harmful practice should be banned from combat sports [29]. Moreover, alternative means of weight loss such as gradual weight loss at the rate of about 1 kilogram per week, elevated carbohydrate intake and emphasis on weight loss from fat depots have been proposed [40]. Accordingly, strict regulations that will emphasize fairness and prioritize athlete's health are needed to bring about much-needed change towards alleviation of RWLinduced consequences in combat sport athletes.

The current study comes with two main limitations: first, it has only an explorative purpose, therefore no causal inference has been done on the collected data. Moreover, questions about RWL could be sensitive to 
social desirability, thus participants could have been biased in their answers, even though we ensured that the questionnaire was totally anonymous.

Nevertheless, the study covers a topic that has never been addressed previously in sambo athletes and it was administered in people from more than 20 nations from all over the world. Since the majority of sambo athletes did not consult physician or dietitian about RWL, the results of the current study pertain primarily to coaches who should upgrade their knowledge about the risks of adopting RWL techniques, whereby athletes' health will be the utmost priority.

\section{Conclusions}

Nearly $87 \%$ of sambo athletes reported to have intentionally cut their weight prior to the competition, whereby $5.27 \mathrm{~kg}$ (SD: \pm 7.57 ) was lost. Gradual dieting, sauna use and skipping meals were the most dominant methods used to reduce weight prior to competition. Overall, males tended to lose more weight during RWL and regained more weight after RWL when compared to females. Findings from current study are consistent with results depicted in previously conducted RWL studies in terms of prevalence, magnitude and methods used by combat sport athletes, especially in judo and wrestling. Knowing the hazardous consequences of RWL, alternative methods of sustainable weight loss should be considered.

\section{Abbreviation}

RWL: Rapid Weight Loss

\section{Acknowledgements}

We thank International Sambo Federation (FIAS) for permission to conduct research.

\section{Authors' contributions}

$P D, S T, S E$ and $A B$ conceived and designed the study. PD, FF, NL, AG, VS, BR, $N V, R R, T$, and $A B$ collected, analyzed, and interpreted the data, and wrote the paper. PD, FF, NL, AG, $\Pi$ and $A B$ analyzed and interpreted the data and drafted a previous version of the paper. All authors read and approved the final manuscript.

\section{Funding}

This work has been supported by the Serbian Ministry of Education, Science and Technological Development (179011) and Provincial Secretariat for Higher Education and Scientific Research (142-451-2094).

\section{Availability of data and materials}

The dataset used and/or analyzed during the current study are available from the corresponding author in response to a reasonable request. Due to patient's data privacy data is not made available publicly.

\section{Declarations}

\section{Ethics approval and consent to participate}

The study was conducted according to the Helsinki declaration and ethical approval was obtained from ethics committee of University of Novi Sad, Serbia (Ref. No. 46-06-02/2020-1). Sambo athletes gave written informed consent upon agreement to participate, thirty of them were under 18 years old, written informed consent was obtained from their national team coach as their legal guardian during the championship.
Consent for publication

Not applicable.

\section{Competing interests}

The authors declare that they have no competing interests.

\section{Author details}

${ }^{1}$ Faculty of Sport and Physical Education, University of Novi Sad, Lovcenska 16, Novi Sad 21000, Serbia. ${ }^{2}$ Sport and Exercise Sciences Research Unit, University of Palermo, Palermo, Italy. ${ }^{3}$ Russian State University of Physical Education, Sport, Youth and Tourism, Moscow, Russia.

Received: 24 December 2020 Accepted: 5 April 2021

Published online: 14 April 2021

References

1. Drid P, Tabakov S, Eliseev S, Selimovic N, Jaksic D, Trivic T, et al. Somatotypes of elite male and female junior sambo athletes. Arch Budo. 2018;14:189-95.

2. Trivic T, Eliseev S, Tabakov S, Raonic V, Casals C, Jahic D, et al. Somatotypes and hand-grip strength analysis of elite cadet sambo athletes. Medicine. 2020;99(3):e18819. https://doi.org/10.1097/MD.0000000000018819.

3. Osipov AY, Kudryavtsev MD, Jagiełto W, lermakov SS, Btach W. Increasing of special physical fitness of the female athletes practicing sambo. Arch Budo. 2020;16:53-9.

4. Osipov AY, Kudryavtsev MD, lermakov SS, Jagielło W. The overall knowledge characterising the training process of young sambo athletes. Arch Budo. 2019;15:110.

5. Giannini Artioli G, Gualano B, Franchini E, Scagliusi FB, Takesian M, Fuchs M, et al. Prevalence, magnitude, and methods of rapid weight loss among judo competitors. Med Sci Sports Exerc. 2010;42(3):436-42. https://doi.org/1 0.1249/MSS.0b013e3181ba8055.

6. Alderman BL, Landers DM, Carlson J, Scott JR. Factors related to rapid weight loss practices among international-style wrestlers. Med Sci Sports Exerc. 2004;36(2):24952. https://doi.org/10.1249/01.MSS.0000113668.03443.66.

7. Kiningham RB, Gorenflo DW. Weight loss methods of high school wrestlers. Med Sci Sports Exerc. 2001;33(5):810-3. https://doi.org/10.1097/00005768-200105000-00021.

8. Viveiros L, Moreira A, Zourdos MC, Aoki MS, Capitani CD. Pattern of weight loss of young female and male wrestlers. J Strength Cond Res. 2015;29(11): 3149-55. https://doi.org/10.1519/JSC.0000000000000968.

9. El Berkovich B, Eliakim A, Nemet D, Stark AH, Sinai T. Rapid weight loss among adolescents participating in competitive judo. Int I Sport Nutr Exerc Metab. 2016;26(3):276-84. https://doi.org/10.1123/ijsnem.2015-0196.

10. Khodaee M, Olewinski L, Shadgan B, Kiningham RR. Rapid weight loss in sports with weight classes. Curr Sports Med Rep. 2015;14(6):435-41. https:// doi.org/10.1249/JSR.0000000000000206.

11. Reale R, Slater G, Burke LM. Weight management practices of australian olympic combat sport athletes. Int J Sports Physiol Perform. 2018;13(4):45966. https://doi.org/10.1123/ijspp.2016-0553.

12. Langan-Evans C, Close GL, Morton JP. Making weight in combat sports. Strength Cond J. 2011;33(6):25-39. https://doi.org/10.1519/SSC.0b013e318231bb64.

13. Barley $\mathrm{O}$, Chapman D, Abbiss C. The current state of weight-cutting in combat sports. Sports. 2019;7(5):123. https://doi.org/10.3390/sports7050123.

14. Lakicevic N, Roklicer R, Bianco A, Mani D, Paoli A, Trivic T, et al. Effects of rapid weight loss on judo athletes: a systematic review. Nutrients. 2020; 12(5):1220. https://doi.org/10.3390/nu12051220.

15. Artioli GG, Scagliusi F, Kashiwagura D, Franchini E, Gualano B, Junior AL. Development, validity and reliability of a questionnaire designed to evaluate rapid weight loss patterns in judo players. Scand J Med Sci Sport. 2010; 20(1):e177-e87. https://doi.org/10.1111/j.1600-0838.2009.00940.x.

16. Cadwallader AB, De La Torre $X$, Tieri A, Botrè $F$. The abuse of diuretics as performance-enhancing drugs and masking agents in sport doping: pharmacology, toxicology and analysis. Br J Pharmacol. 2010;161(1):1-16. https://doi.org/10.1111/j.1476-5381.2010.00789.x.

17. Halabchi F. Doping in Combat Sports. In: Combat Sports Medicine. 1st ed; 2009. p. $1-18$

18. Wile D. Diuretics: a review. Ann Clin Biochem. 2012;49(5):419-31. https://doi. org/10.1258/acb.2011.011281

19. Oppliger RA, Steen SAN, Scott JR. Weight loss practices of college wrestlers. Int J Sport Nutr Exerc Metab. 2003;13(1):29-46. https://doi.org/10.1123/ijsnem.13.1.29.

20. Barley OR, Chapman DW, Abbiss CR. Weight loss strategies in combat sports and concerning habits in mixed martial arts. Int J Sports Physiol Perform. 2018;13(7):933-9. https://doi.org/10.1123/ijspp.2017-0715. 
21. Crighton B, Close GL, Morton JP. Alarming weight cutting behaviours in mixed martial arts: a cause for concern and a call for action. Br J Sports Med. 2016;50(8):446-7. https://doi.org/10.1136/bjsports-2015-094732.

22. Brito CJ, Roas AFCM, Brito ISS, Marins JCB, Córdova C, Franchini E. Methods of body-mass reduction by combat sport athletes. Int I Sport Nutr Exerc Metab. 2012;22(2):89-97. https://doi.org/10.1123/ijsnem.22.2.89.

23. El Berkovich B, Stark AH, Eliakim A, Nemet D, Sinai T. Rapid weight loss in competitive judo and taekwondo athletes: attitudes and practices of coaches and trainers. Int J Sport Nutr Exerc Metab. 2019;29(5):532-8. https:// doi.org/10.1123/ijsnem.2018-0367.

24. Sansone RA, Sawyer R. Weight loss pressure on a 5 year old wrestler. Br J Sports Med. 2005;39(1):e2. https://doi.org/10.1136/bjsm.2004.013136.

25. Washington RL, Bernhardt DT, Brenner JS, Gomez J, Martin TJ, Reed FE, et al. Promotion of healthy weight-control practices in young athletes. Pediatrics. 2005:116(6):1557-64. https://doi.org/10.1542/peds.2005-2314.

26. Mendes SH, Tritto AC, Guilherme JPLP, Solis MY, Vieira DE, Franchini E, et al. Effect of rapid weight loss on performance in combat sport male athletes: does adaptation to chronic weight cycling play a role? Br J Sports Med. 2013;47(18):1155-60. https://doi.org/10.1136/bjsports-2013-092689.

27. Oppliger RA, Case HS, Horswill CA, Landry GL, Shelter AC. American College of Sports Medicine position stand. Weight loss in wrestlers. Med Sci Sports Exerc. 1996;28(6):ix-xii.

28. Oppliger RA, Utter AC, Scott JR, Dick RW, Klossner D. NCAA rule change improves weight loss among National Championship Wrestlers. Med Sci Sports Exerc. 2006;38(5):963-70. https://doi.org/10.1249/01.mss.0000218143.69719.b4.

29. Artioli GG, Saunders B, Iglesias RT, Franchini E. It is time to ban rapid weight loss from combat sports. Sport Med. 2016;46(11):1579-84. https://doi.org/1 0.1007/s40279-016-0541-X.

30. Zubac D, Karnincic H, Sekulic D. Rapid weight loss is not associated with competitive success in elite youth Olympic-style boxers in Europe. Int I Sports Physiol Perform. 2018;13(7):860-6. https://doi.org/10.1123/ijspp.2016-0733.

31. Hall CJ, Lane AM. Effects of rapid weight loss on mood and performance among amateur boxers. Br J Sports Med. 2001;35(6):390-5. https://doi.org/1 0.1136/bjsm.35.6.390

32. Fortes L, Costa D, Paes P, Cyrino E, Vianna J, Franchini E. Effect of rapid weight loss on physical performance in judo athletes: is rapid weight loss a help for judokas with weight problems? Int J Perform Anal Sport. 2017;17(5): 763-73. https://doi.org/10.1080/24748668.2017.1399323.

33. Pettersson S, Ekström MP, Berg CM. Practices of weight regulation among elite athletes in combat sports: a matter of mental advantage? J Athl Train. 2013;48(1):99-108. https://doi.org/10.4085/1062-6050-48.1.04.

34. Roklicer R, Lakicevic N, Stajer V, Trivic T, Bianco A, Mani D, et al. The effects of rapid weight loss on skeletal muscle in judo athletes. J Transl Med. 2020; 18(1):142. https://doi.org/10.1186/s12967-020-02315-x.

35. Coswig V, Fukuda D, Del Vecchio F. Rapid weight loss elicits harmful biochemical and hormonal responses in mixed martial arts athletes. Int I Sport Nutr Exerc Metab. 2015;25(5):480-6. https://doi.org/10.1123/ijsnem.2014-0267.

36. Tarnopolsky MA, Cipriano N, Woodcroft C, Pulkkinen WJ, Robinson DC, Henderson JM, et al. Effects of rapid weight loss and wrestling on muscle glycogen concentration. Clin J Sport Med. 1996:6(2):78-84. https://doi.org/1 0.1097/00042752-199604000-00003

37. Filaire E, Maso F, Degoutte F, Jouanel P, Lac G. Food restriction, performance, psychological state and lipid values in judo athletes. Int J Sports Med. 2001;22(06):454-9. https://doi.org/10.1055/s-2001-16244.

38. Morales J, Ubasart C, Solana-Tramunt M, Villarrasa-Sapiña I, González LM, Fukuda D, et al. Effects of rapid weight loss on balance and reaction time in elite judo athletes. Int J Sports Physiol Perform. 2018;13(10):1371-7. https:// doi.org/10.1123/ijspp.2018-0089.

39. Remick D, Chancellor K, Pederson J, Zambraaki EJ, Sawka MN, Wenger CB. Hyperthermia and dehydration-related deaths associated with intentional rapid weight loss in three collegiate wrestlers- North Carolina, Wisconsin, and Michigan, November-December 1997. JAMA. 1998;279(11):824-5.

40. Franchini E, Brito CJ, Artioli GG. Weight loss in combat sports: physiological, psychological and performance effects. J Int Soc Sports Nutr. 2012;9(1):52. https://doi.org/10.1186/1550-2783-9-52.

\section{Publisher's Note}

Springer Nature remains neutral with regard to jurisdictional claims in published maps and institutional affiliations.

\section{Ready to submit your research? Choose BMC and benefit from}

- fast, convenient online submission

- thorough peer review by experienced researchers in your field

- rapid publication on acceptance

- support for research data, including large and complex data types

- gold Open Access which fosters wider collaboration and increased citations

- maximum visibility for your research: over $100 \mathrm{M}$ website views per year

At BMC, research is always in progress.

Learn more biomedcentral.com/submissions 